\title{
Aspectual pair, aspectual triplet, aspectual cluster: what is the unit of the category of aspect and can the answer be tested experimentally?
}

\section{Nezrin Samedova-Hajiyeva}

Azerbaijan University of Languages

\begin{abstract}
This paper is an attempt to show that the problem of identifying the unit of the category of Russian aspect indicates the explanatory and predictive potential of an aspectological theory. We introduce a wider scientific community to the theory that regards the aspectual pair (or the two-term / binary paradigm) as the only one unit of the category of Russian aspect and that characterizes the notion of the aspectual triplet as an obstacle to aspectological studies. We show how the theory explains Maslov's (2004) paradox about so-called instantaneous / momentary / punctual verbs such as прыгнуть 'to jump'. The advanced explanation can be tested by cognitive experiments, which will serve as one more argument for the aspectological theory that rejects the notion of aspectual cluster of any type.
\end{abstract}

Key words: aspectual pair, aspectual triplet, aspectual cluster, the unit of the category of Russian aspect, semelfactive / momentary / instantaneous / punctual verbs, Slavic-type aspect, cognitive experiments

\section{The notions of the aspectual pair, aspectual triplet, and aspectual cluster}

“Mysterious" for learners (Młynarczyk, 2004,p. 1) and "a conundrum" for scholars (Paducheva, 2010, p. 9), the category of verb aspect in Slavic is, nevertheless, successfully studied. This is all the more paradoxical given that there is a wide range of interpretations of the notion of aspect itself: compare definitions in, e.g., (Vinogradov, 1953, p. 426) and (Comrie, p. 3). Moreover, there appears to be only one thesis unanimously accepted by researchers undertaking aspectological studies. The thesis is that the category of aspect that modern Slavic languages possess is of the same type (e.g. Moldovan et al., 2005). 
Thus, it is hardly surprising that the unit of the category (or "the aspectual paradigm", in terms of the theory we follow) is a debated topic. The "nominees" are the aspectual pair, aspectual triplet, and aspectual cluster. We introduce them below in the order in which they have come on the scientific scene.

The notion of the aspectual pair was developed by the Slavistic tradition (for the background of the idea, see Vinogradov, 1986, pp. 393-439). To appreciate this intuitive insight, let us have a look at a group of Russian verbs that represent the same derivational family. ${ }^{1}$

Note that:

- active voice verbs are only given (in order to keep the explanation as simple as possible);

- there are hundreds of such groups in Russian;

- a similar example can also be provided from any other Slavic language: ${ }^{2}$

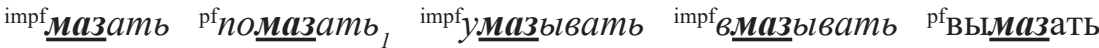

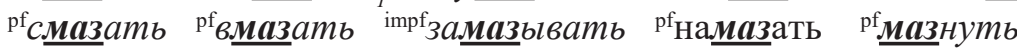

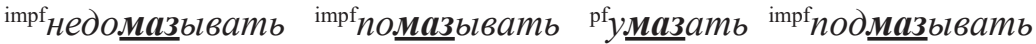

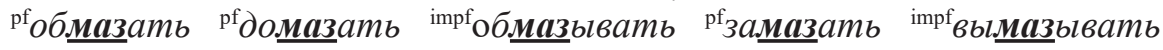

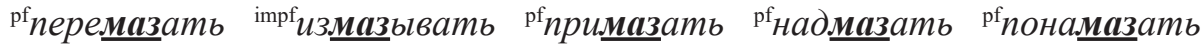

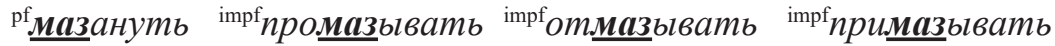

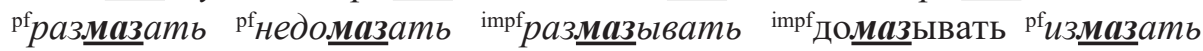

$$
\begin{aligned}
& { }^{\mathrm{pf}} \text { понамазывать }{ }^{\mathrm{pf}} \text { отмазать }{ }^{\mathrm{pf}} \text { промазать ітре надмазывать }
\end{aligned}
$$

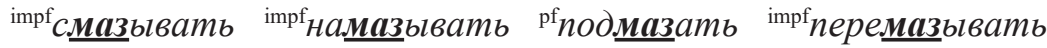

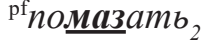

And now let us turn to another way of presenting these verbs. Below they are given as (purely) aspectual pairs, i.e. as pairs that consist of an imperfective and a perfective each of which has only one differential semantical element (see, e.g., Samedov, 1975; Samedov, 1978; Samedov, 1982; Samedov, 1987). One can notice that already at the visual level, the notion of aspectual pair makes it evident that there are cases when two verbs of different aspect that belong to the same derivational nest are characterized with "maximal" semantic similarity and "minimal" semantic difference. See, for instance:

${ }^{1}$ I have added some verbs to the list given in (Tikhonov, 1985, pp. 564-566) to present a fuller picture (the suggestions have been verified through the Russian National Corpus and internet). Note also that the tags 'impf' and 'pf' are for imperfective and perfective verbs, respectively.

${ }^{2}$ Here and elsewhere, neither translation, nor glosses are provided when they are irrelevant and only distract the reader. As for bolding and underlining of roots, their purpose is to concentrate the reader's attention on similarities and differences of the morphemic structure of the words and, consequently, their semantics. 
Aspectual pair, aspectual triplet, aspectual cluster: what is the unit of the category of aspect...

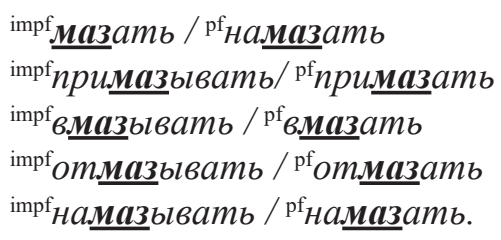

The notion of aspectual pair has been elaborated within the structuralist approach, see, among others, the earliest attempt by Jakobson (1984a; 1984b) and the one by Samedov $(1975 ; 1978)$. There are still researchers who explicitly point out that "the foundation of the category of aspect is known to rest on aspectual pairs" (Potekhina, 2007). Importantly, teaching the Russian verb to foreigners is still built upon memorizing aspectual pairs, see, for example, the internet sites for teaching Russian as a foreign language (The aspect of the Russian verb: to accept and love, 2014; Russian verb drills, 2018).

As for the aspectual triplet, one can get the idea of it if they combine two aspectual pairs given above into a derivation chain. Compare, e.g., on the one hand,

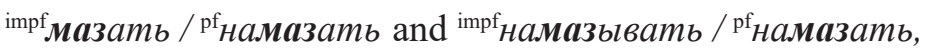

and, on the other hand,

${ }^{\mathrm{impf}}$ мазать / ${ }^{\mathrm{pf}}$ Hамазать / impf Haмазывать.

The notion of the aspectual triplet has appeared in the context of Karcevski's (2004) view on the scope of aspectual pairs. Karcevski (ibid., p. 119) believed that "the formation of aspect is completely based on verbal derivation and is nothing but a particular case of verbal derivation as a whole". Consequently, when combining verbs into aspectual pairs, one should take their derivation chain into account.

From all the notions considered, this one is firmly established and gets almost no criticism. Thus, I know only one theory that characterizes the notion of the aspectual triplet as an obstruction to the study of aspect (Samedova, 2010). More to the point, the ever-increasing quantity of such imperfectives as impf (the so-called secondary imperfectives) leads researchers to the conclusion that "the forming three-term category is starting to loom through the two-term one" (Shatunovskiy, 2011, p. 9), also see (Soboleva, 2018).

Finally, let us have a look at the notion of the aspectual cluster. It is introduced by Laura Janda who leads a team of experienced researchers in the Arctic University of Norway. Janda emphasizes that she is not the first one who raises "doubts about 
the validity of the "pair" model" (Janda, 2007, p. 642). The scholar blames the model for ignoring the fact that most verbs exist in larger clusters of three or more aspectually related forms (ibid., p. 607). She believes that it is the notion of the aspectual cluster that has made distinguishing among perfectives possible (ibid.). The scholar $(2012$, p. 37) explicitly states that the notion of aspectual triplet is incompatible with the "paired" model of the Russian aspect: "The triples... pose a problem for the "paired" model of the Russian aspect [...]."

To elucidate the notion of the aspectual cluster, Janda suggests the visual metaphors of diagram ${ }^{3}$ (Janda, 2007, p. 621) and table (Janda, Korba, 2008). See Figure 1 and Table 1, respectively:

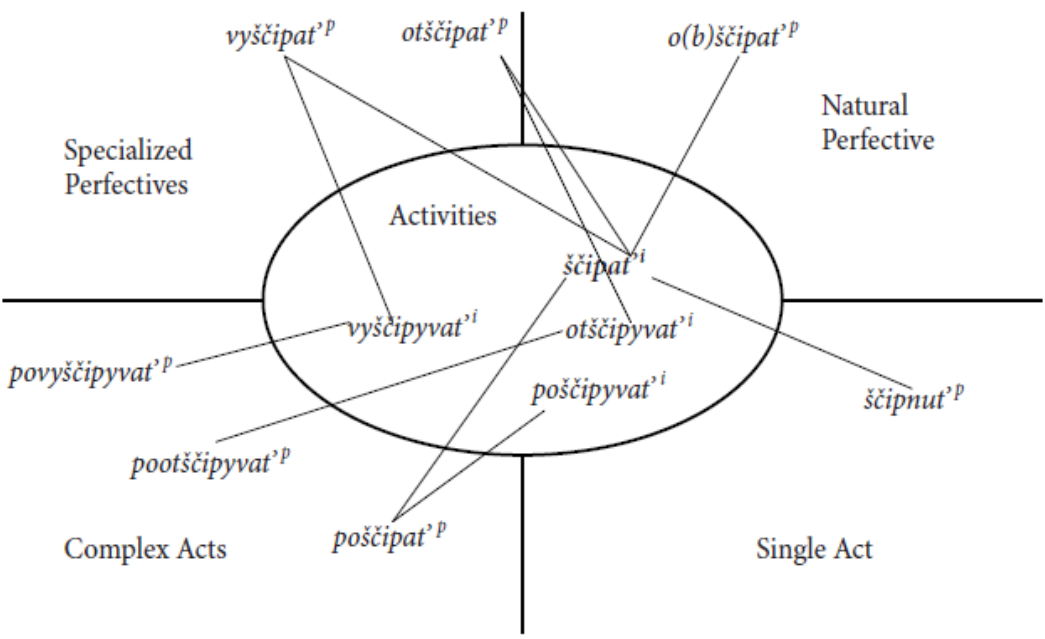

Fig. 1. The verb cluster exemplified by the verb ųunams

Table 1 . The verb cluster headed by мазать ${ }^{4}$

\begin{tabular}{|c|c|c|c|c|c|}
\hline Activity & $\begin{array}{c}\text { Natural Per- } \\
\text { fective }\end{array}$ & $\begin{array}{l}\text { Specialized } \\
\text { Perfective }\end{array}$ & $\begin{array}{l}\text { Derived Imper- } \\
\text { fective }\end{array}$ & $\begin{array}{l}\text { Complex Act } \\
\text { Perfective }\end{array}$ & $\begin{array}{l}\text { Single Act } \\
\text { Perfective }\end{array}$ \\
\hline \multirow[t]{3}{*}{$\underline{\text { маз }} a \mathrm{mb}$} & & & & $\operatorname{noмa3} \mathrm{mmb}_{2}$ & $\begin{array}{r}\text { маз нутьв } \\
\text { мазануть }\end{array}$ \\
\hline & & вмазать & вмазывать & & \\
\hline & выммазать & & вымазывать & & \\
\hline
\end{tabular}

3 About visual metaphors used in science, see (Brown, 2008).

${ }^{4}$ The table is our attempt to arrange the verbs of the derivational family given earlier in the aspectual cluster. When arranging, we proceeded from (Janda, Korba, 2008; Makarova, Janda, 2009; Janda, 2007, p. 621; Janda, 2015; Exploring emptiness, 2019). 
Aspectual pair, aspectual triplet, aspectual cluster: what is the unit of the category of aspect...

\begin{tabular}{|c|c|c|c|c|c|}
\hline Activity & $\begin{array}{l}\text { Natural Per- } \\
\text { fective }\end{array}$ & $\begin{array}{l}\text { Specialized } \\
\text { Perfective }\end{array}$ & $\begin{array}{l}\text { Derived Imper- } \\
\text { fective }\end{array}$ & $\begin{array}{l}\text { Complex Act } \\
\text { Perfective }\end{array}$ & $\begin{array}{l}\text { Single Act } \\
\text { Perfective }\end{array}$ \\
\hline & & домазать & домазывьвать & & \\
\hline & $3 a \underline{\text { мaз }} a m b$ & & замаз & & \\
\hline & измазать & & измазывать & & \\
\hline & & надмазать & надмазывать & & \\
\hline & намазать & & намазывьвать & & \\
\hline & & недомазать & недомаз йвать & & \\
\hline & & обмазать & обмазйвать & & \\
\hline & & отмазать & отмазывать & & \\
\hline & & перемазать & перемазывать & & \\
\hline & & подмазать & подмазйвать & & \\
\hline & помазать & & помазывать & & \\
\hline & & понамазать & понамаз ывать & & \\
\hline & & примазать & примазывать & & \\
\hline & промазать & & промазывьвать & & \\
\hline & & размазать & размазывать & & \\
\hline & & смазать & смазывать & & \\
\hline & & $y_{\text {мазаз }} а т ь$ & умазывать & & \\
\hline
\end{tabular}

\section{In defense of the aspectual pair}

The work of Janda's team (the CLEAR research group) has "induced" publishing the near-400-page influential book with the self-evident title "Russian Aspectology: In the Defense of the Aspectual Pair" (Zaliznyak, Mikaelyan, Shmelyov, 2015). The authors qualify the notion of aspectual pair as the most important instrument for describing the linguistic competence of the native Russian speaker (ibid., p. 232). Throughout the entire book, they provide ample evidence of the value of the notion both for language studies and language pedagogy.

The linguists also rigorously analyze the model of aspectual clusters. Thus, they show that Janda and her team have failed to suggest strict criteria for differentiating between natural and specialized perfectives, ${ }^{5}$ see, e.g., (ibid., p. 261).

Interestingly, the researchers agree that aspectual triplets are also clusters. However, they think that the existence of aspectual triplets by no means disproves

${ }^{5}$ See Table 1, to get the idea of the perfectives. 
the theory of aspectual pairedness. They treat triplets as an inherent constituent of the Russian aspectual system. See, e.g., (ibid., p. 233, 247, 270).

It is also interesting that their opponents declare aspectual pairs as the cornerstone of on which they build the cluster model that is aimed at classifying Russian perfectives in particular and describing the structure of the Russian aspect system in general (Janda, 2015).

In this paper, we acquaint a wider audience with the theory that regards the aspectual pair as one and only one unit of the category of aspect. The following is a concrete case through which we intend to demonstrate the explanatory potential of the theory.

\subsection{A challenge for aspectual theories}

Let us examine a paradox that remains a challenge for theories that operate with the notion of aspectual cluster of any type, including the aspectual triplet (for the detailed substantiation of the thesis, see Samedova, 2011b; Samedova, 2017). We name the puzzle Maslov's paradox because it has been revealed due to incisive observations by Yuriy S. Maslov.

Maslov's paradox is about verbs like the Russian perfective прыгнуть 'to make a jump'. Their meaning is traditionally described as "momentary", "instantaneous", "punctual" by proponents of various aspectual theories, see, e.g., (Karcevski, 2004, p. 123; Plungyan, 1998, p. 376). Indeed, these terms adequately reflect linguistic intuition of even an ordinary native speaker, compare прыгнуть (до стола) 'pfto get (to the table) in one jump' and допрыгать (до стола) ' ${ }^{\text {pft }}$ to get (to the table) in a few jumps'. On the other hand, this description does not agree with the potential of such verbs to combine with units like медленно 'slowly' (Maslov, 1959, pp. 185, 227).

\subsection{The proposed solution: four steps}

2.2.1. The proposed perspective is illustrated by the example of the perfectives прыгнуть and допрыгать. ${ }^{6}$ First of all, we suggest rethinking the idea that these verbs are correlated with the same imperfective прыгать. The opinion we substantiate below is that the homonymous imperfectives прыгать and прыгать $_{2}{ }^{7}$ should be differentiated as they reveal significant differences with regard to their behavior and systemic relationships. Thus, the latter has the following distinctive features:

\footnotetext{
${ }^{6}$ Henceforward, see 2.1 for the translations of the verbs.

7 Their meaning will be explicated in 2.2.2.
} 
1. Прыгать 2 combines with медленно ('slowly') only in situations like commenting on a slowed down film (Comrie, 1976, p. 42-43): Кот медленно прыгает ${ }_{2}$ на диван ('The cat slowly jumps on the sofa').

2. Прыгать ${ }_{2}$ is compatible with words and phrases that indicate duration only if they denote an extremely short time span, e.g., за долю секунды ('in a split second'): За долю секунды он прыгает ${ }_{2}$ на диван ('Hе jumps on the sofa in a split second').

3. Прыгать ${ }_{2}$ occurs in the constructions with phasal verbs only in situations like describing a slow motion effect, e.g.: Смотри! Хавьер Сотомайор начал прыгать ${ }_{2}$ свой рекордный прыжок! ('Look! Javier Sotomayor started jumping his world record jump!'). А в это мгновенье Сотомайор закончил прыгать ${ }_{2}$ ! ('And at this instant Sotomayor finished jumping!').

4. Прыгать ${ }_{2}$ does not correlate with the following four perfectives:

- запрыгать: *Парашютист оттолкнулся от края люка $и$ запрыгал ${ }^{9}$ (*AA parachute jumper pushed off the hatch edge and started jumping');

- попрыгать: *Парашютист оттолкнулся от края люка и попрыгал (*'A parachute jumper pushed off the hatch edge and jumped for a while');

- пропрыгать: *Парашютист оттолкнулся от края люка и пропрыгал 5 минут (*'A parachute jumper pushed off the hatch edge and jumped for 5 minutes');

- отпрыгать: *Парашютист оттолкнулся от края люка и отпрыгал (*'A parachute jumper pushed off the hatch edge and finished jumping').

However, прыгать ${ }_{2}$ is a correlate of прыгнуть: Парашютист отталкивается от края люка и прыгает ('A parachute jumper pushes off the hatch edge and jumps') / Парашютист оттолкнулся от края люка и прыгнул ('A parachute jumper pushed off the hatch edge and jumped').

5. Прыгать 2 is not correlative with the members of the (purely) aspectual paradigm допрыгивать / допрыгать: *Парашютист допрыгивал / допрыгал второй прыжок (*'A parachute jumper was finishing / finished jumping his second jump').

However, it correlates with the members of the (purely) aspectual paradigm допрыгивать / допрыгнуть: Он был такой высокий, что с лёгкостью допрыгивал / допрыгнул до потолка ('He was so tall that he jumped to the ceiling with ease').

2.2.2. The described properties lead us to the conclusion that homonymous

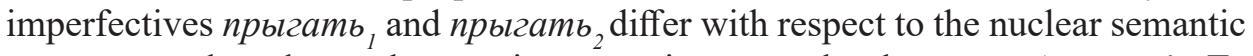
component that the verb meaning contains, namely the seme 'process'. To

\footnotetext{
${ }^{8}$ The sentence has been modelled following the example in (Chertkova, 1996, p. 70).

9 The asterisk marks unacceptable sentences.
} 
identify the nature of the seme, we rely on Maslov's 1948 paper where the scholar 1) presents the first linguistic taxonomy that correlates semantic properties of a verb with properties of the event the verb refers to (Maslov, 2004, p. 90) and 2) shows why semelfactives hold a special place within the classification (ibid., pp. 84, 88-89). Thus, we proceed from the fact that, unlike npwzamb $_{1}$, the verb nрыгamb ${ }_{2}$ refers to a very brief physical action (namely one jump) that takes some fraction of a second to happen. We conclude that the action is conceptualized in full accordance with this characteristic and the language "congruently" fixes the conceptualization. Thus, the verb npblzamb ${ }_{2}$ is characterized with the seme 'process of non-standard (namely short) duration'. (Compare the idea in (Bott, 2010, p. 1): "[...] the encoding of events in language directly reflects fundamental ontological distinctions between event types".)

As one can infer from the term "process of non-standard (namely short) duration", we attribute the imperfective npblzamb the seme 'process of standard duration'. This verb refers to jumps that happen unceasingly during a period of time. Note that the language does not distinguish how many jumps happen - only two or more. In any case the action is conceptualized as having the same duration as processes denoted by such verbs as walk, dance, cook, read, sleep, etc. (The conceptualisation is distinct, however, in one - it is perceived as discrete, as a dashed line, though it is a whole unit, see (Rothstein, 2016, p. 345) - but we will not consider it here as it is beyond the scope of the paper.) The visual metaphors we use for illustrating the postulated homonyms authentically reflects their decisive seme as to its duration. (Note that both the absolute and relative lengths of the visual metaphors are conventional.)

\section{npolaamb 1}

\section{npaleamb 2}

Fig. 2. The postulated homonymous imperfectives

Differentiated imperfectives are awaiting apt terms. So far we refer to them as momentary (npblzamb ${ }_{2}$ "to jump once") and non-momentary (nрыгать ${ }_{1}$ "to jump more than once") as a second-best choice. The signifiers are misleading in the sense that they give an impression that in language, there exist verbs that do not have the seme 'process'.

2.2.3. Like the momentary imperfective nрыгать ${ }_{2}$, the perfective прыгнуть has the seme 'process of short duration'. See the semantic properties of the verb: 
Aspectual pair, aspectual triplet, aspectual cluster: what is the unit of the category of aspect...

1. It is compatible with медленно ('slowly') only in situations like watching a slow motion video: Кот медленно прыгнул на диван ('The cat slowly jumped on the sofa').

2. It is compatible with "extent" (the term introduced by Haspelmath, 1997) phrases only if they indicate extremely short duration: За долю секунды он прыгнул на диван ('He jumped on the sofa in a split second').

3. Прыгнуть demonstrates a strong semantic resemblance to the momentary прыгать ${ }_{2}$. See, for instance, two sentences that are translated identically: Брумель уже прыгал? / Брумель уже прыгнул? - Has Brumel already juтреd?

2.2.4. Finally, we will set forth the explanation we offer for the linguistic intuition about the perfective прыгнуть "pf to jump once". Like any perfective, прыгнуть is characterized with the aspectual seme that has an extraordinary cognitive nature: it is a point that attracts our attention. As the attention focuses on the seme, the meaning of a perfective verb is in some way misperceived. In particular, the essential cognitive characteristic of the seme 'process', namely duration, gets concealed (see (Samedova, 2015) for more about the idea ${ }^{10}$ ). Consequently, the impression arises that a perfective verb has no seme 'process' at all.

Thus, in both прыгнуть and допрыгать our attention concentrates on the aspectual seme 'final bound' ('final point', 'final moment'). However, in допрыгать, it is the seme 'process of standard duration' that is backgrounded, whereas in прыгнуть, the overshadowed seme is 'process of short duration' (see Fig. 3). That is why the native speaker has the false idea that прыгнуть is "momentary", "instantaneous", "punctual".

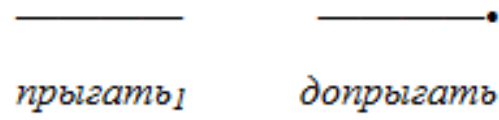

Fig. 3. The aspectual correlates прыгать ${ }_{1} /$ допрыгать and прыгать ${ }_{2} /$ прыгнуть

${ }^{10}$ For example, Karcevski describes perfectivation as "nothing else but the concentration of our attention on one concrete moment of a process, it is the concentration that excludes all other moments, hence the impression that the perfective process has no duration at all, however we will say that it is only an impression, since any process inevitably has some length" (Karcevskii, 2004, p. 125). 


\section{Expected experimental evidence}

There are grounds to think that the proposed solution can be tested experimentally, see investigations of similar phenomena in (Bott, 2008; Bott, 2010; Bott, Gattnar, 2015; Bott, 2017; Brennan, Pylkkänen, 2008; Paczynski et al., 2010; Paczynski et al., 2014; Piñango et al., 2006; Yano, 2017; Klimek-Jankowska et al., 2018). Thus, experiments carried on English equivalents of the verbs considered and other socalled semelfactives show that there are significant differences in their neural processing that depend on whether the verb appears in "punctive", "explicitly iterative", or "durative" context, see, e.g., (Paczynski et al., 2010). A special hope is given by the study of processing perfective and imperfective verbs in Polish (Klimek-Jankowska et al., 2018).

The theory I follow predicts that experiments will draw a clear line between purely aspectual paradigms like прыгать ${ }^{\text {Мот }} /$ прыгнуть, on the one

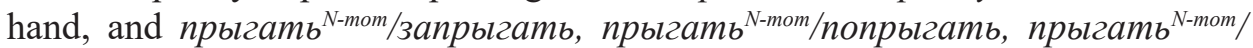

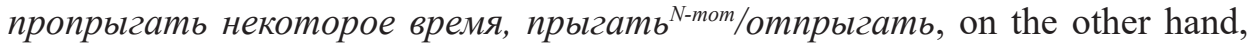
with regard to the critical cognitive property their members possess.

Of special interest is contrastive examination of contexts where the nрыгать ${ }^{\text {Mom }}$ and $п$ рыгатат ${ }^{\mathrm{N} \text {-mom }}$ can be unequivocally identified with contexts that are ambiguous (e.g., Ты видел, когда он прыгал? 'Did you see him jumping?').

\section{Two words about the theory behind the suggested resolution ${ }^{11}$}

The theory is distinct for the consistent application of the classical structuralist method of opposition. This approach has enabled its founder to reveal the logical consequence of employing the notion of aspectual triplet. The thesis that in Russian there are three-member chains that consist of a simple imperfective, perfective, and secondary imperfective (e.g., мазать - намазать - намазывать) leads to the conclusion that in the language there are neither prefixal nor suffixal purely aspectual paradigms (Samedov, 1971; Samedov, 1982; Samedov, 1987). This conclusion, in its turn, means that the category of aspect is not a grammatical phenomenon.

Thus, according to the theory, indeed, the notion of aspectual triplet is a threat to the notion of purely aspectual pair. The solution is to replace the traditional

${ }^{11}$ For more information about the theory, the foreign reader can refer to (Samedova, 2011a-b; Samedova, 2013a-b; Samedova, 2015; Samedova, 2018a-b; Samedova, 2019; Samedova, 2020). 
opinion with the consistently structuralist perspective that postulates purely aspectual paradigms perfective members of which are homonyms that differ semantically/structurally: мазать / намазать, и намазывать / намазать .

\section{Conclusion}

The consistently structuralist analysis of perfectives like прыгнуть draws linguists' attention to the non-traditional view on the notion of the aspectual triplet. The resolution of Maslov's paradox lets us state that building the explanatory and predictive model of the Russian aspect becomes possible if to recognise that the category of aspect has the only one unit and the unit is the two-term (binary) aspectual paradigm. We suppose that results described in (Samedova, 2011a; Samedova, 2013a-b; Samedova, 2015; Samedova, 2016; Samedova, 2018a-b; Samedova, 2019; Samedova, 2020) also allow thinking that the theory we work within can effectively respond to challenges posed by Slavic-type aspect.

\section{References}

Bott, O. (2008). Doing it again and again may be difficult - but it depends on what you are doing. In Proceedings of the 27th West Coast Conference on Formal Linguistics, (pp. 63-71). Somerville, MA: Cascadilla Proceedings Project.

Bott, O. (2010). The Processing of Events. Amsterdam: John Benjamins.

Bott, O. (2017). Context reduces coercion costs - evidence from eyetracking during reading. In Proceedings of the 39th Annual Meeting of the Cognitive Science Society "Computational Foundations of Cognition", (pp. 1654-1660). London, UK.

Bott, O., Gattnar, A. (2015). The cross-linguistic processing of aspect - an eyetracking study on the time course of aspectual interpretation in Russian and German. Language, Cognition and Neuroscience, 30, 7, 877-898.

Brennan, J., Pylkkänen, L. (2008). Processing events: Behavioral and neuromagnetic correlates of aspectual coercion. Brain \& Language, 106, 132-143.

Brown, Th. L. (2008). Making truth: Metaphor in science. Urbana \& Chicago: University of Illinois Press.

Chertkova, M. Yu. (1996) - Черткова М.Ю. Грамматическая категория вида в современном русском языке. Москва: Издательство Московского университета.

Comrie, B. (1998). Aspect. Cambridge: Cambridge University Press.

Exploring emptiness (2019). http://emptyprefixes.uit.no/index.php

Haspelmath, M. (1997). From space to time. Temporal adverbials in the world's languages. München; Newcastle: Lincom Europa.

Jakobson, R. (1984a). Shifters, verbal categories, and the Russian verb. In R. Jakobson, Russian and Slavic grammar. Berlin-New York-Amsterdam: Mouton Publishers, pp. 41-58. 
Jakobson, R. (1984b). Structure of the Russian Verb. In R. Jakobson, Russian and Slavic grammar. Berlin-New York-Amsterdam: Mouton Publishers, pp. 1-14.

Janda, L. (2007). Aspectual clusters of Russian Verbs. Studies in Language, 31, 3, 607-648.

Janda, L. (2012) - Л. А. Янда. Русские приставки как система глагольных классификаторов. In Вопросы языкознания, 6, 3-47.

Janda, L. (2015). Verbal Prefixation in Russian: A Rebuttal. Mundo Eslavo, 14, 7-25.

Janda, L., Korba, J. (2008). Cluster types for Russian verbs. http://ansatte.uit.no/laura.janda/clusters/ clusterfrontpage.html

Karcevski, S. I. (2004) - С. И. Карцевский. Система русского глагола. In С. И. Карцевский. Из лингвистического наследия. Том 2. Москва, 31-207.

Klimek-Jankowska, D., Czypionka, A., Wikowski, W., Błaszczak, J. (2018). Time course of processing perfective and imperfective aspect in Polish: Evidence from self-paced and eyetracking experiments. Acta Linguistica Academica, 65(2-3), 293-351.

Makarova, A., Janda, L.A. (2009). Do it once: a case study of the Russian -Hy- semelfactives. Scando-Slavica, 55, 78-99.

Maslov, Yu. S. (2004) - Ю. С. Маслов. Глагольный вид в современном болгарском литературном языке (значение и употребление). Вопросы грамматики болгарского литературного языка. Москва: Издательство АН СССР, 157-312.

Młynarczyk, A. (2004). Aspectual Pairing in Polish. Utrecht: LOT.

Moldovan, A. M. et al. (2005). А. М. Молдован и др. Языки мира: Славянские языки. Москва: Академия.

Paczynski, M., Ditman, T., Choi, A., Jackendoff, R., \& Kuperberg, G. (2010). The immediate cost of embodied processing in aspectual coercion: Evidence from event-related potentials. In The 23rd Annual CUNY Conference on Human. Sentence Processing, New York, (p. 185).

Paczynski, M., Jackendoff, R., \& Kuperberg, G. (2014). When events change their nature: The neurocognitive mechanisms underlying aspectual coercion. Journal of Cognitive Neuroscience. Sep. 26(9), 1905-1917.

Paducheva, Ye. V. (2010) - Е. В. Падучева Семантические исследования. Москва: Языки славянской культуры.

Piñango, M., Winnick, A., Ullah, R., \& Zurif, E. (2006). Time-course of semantic composition: the case of aspectual coercion. Journal of Psycholinguistic Research, 35, 233-244.

Plungyan, V. А. (1998) - В.А. Плунгян. Перфектив, комплетив, пунктив: Терминология и типология. In Типология вида: проблемы, поиски, решения. Москва: Языки русской культуры, pp. 370-381.

Potekhina, Ya. V. (2007) - Потехина Я. В. Префиксальная видовая пара русского глагола и её отражение в словаре. (Unpublished doctoral dissertation). Российский университет дружбы народов. Moscow.

Rothstein, S. (2016). Aspect. M. Aloni and P. Dekker (eds.), The Cambridge Handbook of Formal Semantics. Cambridge University Press, Cambridge, 342-368.

Russian verb drills. (2019). https://www.russianverbdrills.com/

Samedov, G. S. (1971) - Г. С. Самедов. О так называемой перфективации и имперфективации в русском языке. In Материалы научной сессии профессорско-преподавательского состава, посвящённой итогам научно-исследовательских работ за 1970 год. Баку: АПИРЯЛ им. М. Ф. Ахундова, pp. 17-20.

Samedov, G. S. (1975) - Г. С. Самедов. О видовых, чистовидовых и нечистовидовых корреляциях. In Актуальные проблемы исследования грамматического строя современного русского языка. Баку: АПИРЯЛ им. М. Ф. Ахундова, pp. 37-38. 
Samedov, G. S. (1978) - Г. С. Самедов. О понятии видовая корреляция. In Учёные записки АГУ им. С.М. Кирова. “Серия языка и литературы”, 2, pр. 22-26.

Samedov, G. S. (1982) - Г. С. Самедов. Об одной преграде на пути изучения глагольного вида. In Вопросы грамматической структуры азербайджанского языка. Баку: Издательство АГУ им. С. М. Кирова, рр. 35-40.

Samedov, G. S. (1987) - Г. С. Самедов. О так называемых трехчленных цепях с синонимичными крайними членами. In Лексическая и грамматическая синонимия в русском языке. Баку: Издательство АГУ им. С. М. Кирова, 11-21.

Samedova, N. G. (2010) - Н. Г. Самедова. Об одной аспектологической теории (в связи с вопросом о потенциале структурной лингвистики). In Теоретическая и прикладная лингвистика: пути развития. Москва: Издательство Московского университета, 77-78.

Samedova, N. G. (2011a) - Н. Г. Самедова. К вопросу о форме будущего времени глаголов несовершенного вида в современном русском языке. In Логический анализ языка. Лингвофутуризм. Москва: Индрик, 263-276.

Samedova, N. G. (2011b) - Н. Г. Самедова. О статусе видовой парадигмы прыгать / прыгнуть. In Категории глагольной множественности в славянских и неславянских языках (синхрония и диахрония). Скопје: Универзитет “Св. Кирил и Методиј”, 59-78.

Samedova, N. G. (2013a) - Н. Г. Самедова. Aspectual and non-aspectual initiality: on evidence for their differentiation. In Romano-Bohemica II. Journal for Central European Studies, 2, $109-124$.

Samedova, N. G. (2013b) - Н. Г. Самедова. Омонимические конструкции стать+инфинитив: Закономерности поведения. In Acta universitatis szegediensis. Dissertationes slavicae sectio linguistica XXX,151-170.

Samedova, N. G. (2015) - Н. Г. Самедова. Перфективность и сема 'процесс': О когнитивном аспекте взаимодействия. In Аспектуальная семантическая зона: типология систем и сценарии диахронического развития, Киото: Университет Киото Сангё, 248-254.

Samedova, N. G. (2016). Verbs of locomotion like идти (to go) - ходить (to walk): Some thoughts on their semantic description. Lege artis. Language yesterday, today, tomorrow, 1, 308-357.

Samedova, N. G. (2017) - Н. Г. Самедова. Об одном парадоксе, выявленном Ю.С. Масловым. In Вестник Санкт-Петербургского университета. 1, 89-103.

Samedova, N. G. (2018a) - Н. Г. Самедова. Об одном аспекте взаимодействия категорий вида и времени. In La relation temps/aspect: approches typologique et contrastive. Lille: Université Charles-de-Gaulle - Lille 3, 349-355.

Samedova, N. G. (2018b) - Н. Г. Самедова. Имперфективы типа ходить и перфективы типа сходить: Статус аспектуальных отношений. In Материалы Международной конференции русистов в Барселонском университете. Барселона: Trialba Ediciones, 1482-1494.

Samedova, N. G. (2020) - Н. Г. Самедова. Временна́я парадигма русского глагола: О значении так называемого презенса совершенного вида. In Материалы 7-й Международной аспектологической конференции "Взаимодействие аспекта со смежными категориями". Санкт-Петербург.

Samedova, N. G. (2019) - Н. Г. Самедова. Имперфективы типа идти и перфективы типа пойти: Статус аспектуальных отношений. In Славистички студии. Бр.19. Скопье: Универзитет “Св. Кирил и Методиј”.

Shatunovskiy, I. В. (2009) - И. Б. Шатуновский. Проблемы русского вида. Москва: Языки славянских культур.

Soboleva, V. S. (2018). - В. С. Соболева. О семантических особенностях глаголов вторичной имперфективации: Их не/совместимость со значениями длительности и законченности. 
In Актуальные проблемы и перспективы русистики. Барселона: Trialba Ediciones, $1516-1528$

The aspect of the Russian verb: to accept and love. (2014). https://skype-language.com/en/article/ vid-glagola-v-russkom-yazyke-ponyat-i-polyubit.

Tikhonov, А. N. (1985) - А. Н. Тихонов. Словообразовательный словарь русского языка. Том 1. Москва: Русский язык.

Vinogradov, V. V. (ed.) (1953) - В. В. Виноградов (ред.) Грамматика русского языка. (Том 1). Москва: Изд-во АН СССР.

Vinogradov, V. V. (1986) - В. В. Виноградов. Русский язык. Москва: Высшая школа.

Yano, M. (2017). Predictive processing of aspectual information: Evidence from event-related brain potentials. In Language, Cognition and Neuroscience (volume 33, 6), 718-733.

Zaliznyak, A. A., Mikaelyan, I. L., Shmelyov, A. D. (2015) - Анна А. Зализняк, И. Л. Микаэлян, А. Д. Шмелёв. Русская аспектология: В защиту видовой пары. Москва: Языки славянской культуры. 